\title{
Lactating Adenoma
}

National Cancer Institute

\section{Source}

National Cancer Institute. Lactating Adenoma. NCI Thesaurus. Code C9473.

A tubular type adenoma of the breast in which, during pregnancy and lactation, the epithelial cells show extensive secretory changes. 